25. MacGarry, J. D., Guest, M. J., and Foster, D. W.: Ketone body metabolism in the ketosis of starvation and alloxan diabetes. J Biol. Chem., 245: 4382 (1970).

26. Menkes, J. H.: The pattern of urinary alpha keto acids in various neurological diseases. Amer. J. Dis. Child. 99: 500 (1960).

27. Montpetit, V. J. A., Andermann, F., Carpenter, S., Fawcett, J. S., ZborowskaSluis, D., and Giberson, H. R.: Subacute necrotizing encephalomyelopathy. Brain, 94: 1 (1971).

28. Pincus, J. H.: Subacute necrotizing encephalomyelopathy (Leigh's disease): A consideration of clinical features and etiology. Develop. Med. Child Neurol. 14: 98 (1972).

29. Pincus, J. H., Cooper, J. R., Katalin, P., and Turner, V.: Specificity of the urine inhibitor test for Leigh's disease. Neurology, 24: 885 (1974).

30. Sakurai, Y., Fukuyoshi, Y., Hamada, M., Hayakaua, T., and Koike, M. Mammalian alpha-keto acid dehydrogenase complexes. VI. Nature of the multiple forms of pig heart lipoamide dehydrogenase. J. Biol. Chem., 245: 4453 (1970).

31. Shaw, K. N. F.: Unpublished observations.

32. Siess, E. A., and Wieland, O. H.: Purification and characterization of pyruvate dehydrogenase phosphatase from pig heart muscle. Eur. J. Biochem. 26: 96 (1972).

33. Shaw, K. N. F., Gutenstein, M., Jacobs, E. E., and Blaskovics, J. C.: Biochemical screening and monitoring of patients with phenylketonuria and variant forms of hyperphenylalaninemia. In: H. Bickel, F. P. Hudson, and L. I. Woolf: Phenylketonuria, p. 163 (George Thieme, Stuttgart, 1971).

34. Skrede, S., Stromme, J. H., Stokke, O., Lei, S. E. Eldjarn, L.: Fatal congenital lactic acidosis in two siblings. II. Biochemical studies in vivo and in vitro. Acta Pediat. Scand., 60: 138 (1971).

35. Stimmler, L., Jensen, N., and Toseland, P.: Alaninuria associated with microcephaly, dwarfism, enamel hypoplasia, and diabetes mellitus in two sisters. Arch. Dis. Childhood, 45: 682 (1970).

36. Svenningsen, N. W., and Siesjö, B. K.: Cerebrospinal fluid lactate/pyruvate ratio in normal and asphyxiated neonates. Acta. Paediat. Scand., 61: 117 (1972).

37. Tada, K. Sugita, K., Fujitoni, K., Uesaki, T., Takado, G., and Omura, K. Hyperalaninemia with pyruvicemia in a patient suggestive of Leigh's emcephalomyelopathy. Tohoku J. Exp. Med., 109: 13 (1973).

38. Tada, K., Yoshida, T., Konno, T., Wada, Y., Yokoyama, Y., and Arakawa, T. Hyperalaninemia with pyruvicemia. Tohoku J. Exp. Med., 97: 99 (1969).

39. Many of the original articles describing patients with elevated levels of pyruvate and lactate in the blood are enumerated in Reference 4; the others known to us are listed separately.

40. This enzyme is more correctly called pyruvate dehydrogenase, but because of the use of the name pyruvate decarboxylase (from the analogous yeast enzyme, EC. $4.1,1,1)$ in describing the enzyme defect in the first patient with this disorder, it has come into general use. It is in some ways preferable as it bypasses the ambiguity in thinking of the pyruvate dehydrogenase component of the pyruvate dehydrogenase complex.

41. Lactate values in patient 2 and patient 3 were probably neither very accurate nor directly comparable with those done in our laboratory, so numerical values have not been given.

42. We wish to thank Dr. Mario Valente and the Pediatric House Staff for help in caring for the patient; Dr. R. A. Pieter Kark for the neurologic examinations; and Dr. George Popjak for valuable support.

43. This research was supported in part by the State of California Department of Mental Hygiene and by United States Public Health Service Grants HD-04612, HD-00315, HD-05061, HD-06576, HD-05615, and RR-865.

44. The work was presented in part at meetings of the American Society of Human Genetics (Amer. J. Hum. Genet., 24: 23a (1972)) and the American Federation for Clinical Research (Clin. Res., 21: 530 (1973).

45. Requests for reprints should be addressed to: S. Cederbaum, M. D., Neuropsychiatric Institute, 760 Westwood Plaza, Los Angeles, Calif. 90024 (USA).

46. Accepted for publication February 17, 1976.

\title{
Experience with a Direct Reading Dedicated Fluorometer for Determination of Erythrocyte Protoporphyrin
}

\author{
R. KLEIN, (4) P. USHER, AND P. MADIGAN \\ Childhood Lead Poisoning Prevention Program, The Commonwealth of Massachusetts Department of Health, \\ Jamaica Plain, Massachusetts, USA
}

\section{Extract}

Data are presented for erythrocyte protoporphyrin (EP) concentrations determined by the direct reading technique of Lamola $e t$ al. (1). Mean concentration of EP in children whose blood lead concentration was less than $30 \mu \mathrm{g} / \mathrm{dl}$ was $34.7 \mu \mathrm{g} / \mathrm{dl}$ whole blood \pm 13.4 (SD). Mean EP concentration in children with blood lead concentrations of $40-59 \mu \mathrm{g} / \mathrm{dl}$ was $80.8 \mu \mathrm{g} / \mathrm{dl}$. It was $158 \mu \mathrm{g} / \mathrm{dl}$ for children with blood lead concentrations greater than $59 \mu \mathrm{g} / \mathrm{dl}$. All children in this last group had concordant values for $\mathrm{Pb}$ and $\mathrm{EP}$ on the first or second test.

\section{Speculation}

Screening for lead poisoning using capillary blood determination of erythrocyte protoporphyrin as determined by the direct reading dedicated fluorometer is adequate for ascertaining all children in possible need of immediate treatment. The authors believe, however, that screening should be done using both EP and blood lead determinations. The goal of lead poisoning control programs is to eliminate childhood lead poisoning by preventing exposure to lead hazards. Even after elimination of values from children with transient elevation of blood lead concentrations and those with falsely elevated concentrations because of contamination or laboratory error there is a significant number of children with blood lead concentrations of 40-59 $\mu \mathrm{g} / \mathrm{dl}$ who do not have elevated EP concentrations. Opportunities for protecting these children from further lead paint hazards will be lost.

Measurement of erythrocyte protoporphyrin concentration in blood in children at risk for lead poisoning is of recognized value for lead poisoning prevention programs. The development of the direct reading instrument reported by Lamola et al. (1) makes the determination simple and quick. This report relates our experience with a prototype instrument made available to us for use in June-August 1975 (3). 
Determinations were carried out on specimens submitted to the laboratory of the Childhood Lead Poisoning Prevention Program of the Commonwealth of Massachusetts by various individuals, volunteer groups, and health agencies throughout the state for screening or for follow-up of lead poisoning. Fingertip capillary specimens were anticoagulated with EDTA and were protected from light until both lead and erythrocyte protoporphyrin concentrations were measured on the same specimen. Roughly $10 \%$ of specimens were venous samples. These usually were anticoagulated with heparin. Most specimens were received in the laboratory within 10 days of collection. Clotted or hemolyzed specimens were not included in this analysis.

The rate of contamination for $\mathrm{Pb}$ tests on capillary specimens from 60,000 children in this laboratory was under $1.7 \%$. This is equivalent to $23 \%$ of the children in the group with initially elevated blood lead concentrations.

Thirty replicate determinations were performed on each of eight venous samples with EP concentrations of $23-150 \mu \mathrm{g} / \mathrm{dl}$ whole blood. The coefficient of variation was $5.19 \%$. The mean difference between determinations of paired capillary samples obtained from 213 children from the same finger incision was $3.1 \pm 0.21$ (SEM) $\mu \mathrm{g} / \mathrm{dl}$ whole blood. EP concentrations in these specimens ranged from 10 to $700 \mu \mathrm{g} / \mathrm{dl}$. Repeated determinations of two specimens of the same venous blood; one anticoagulated with heparin, the other with EDTA, were carried out for 3 and 5 weeks, respectively. Values of $220-240 \mu \mathrm{g} / \mathrm{dl}$ were obtained for 5 weeks from the EDTA aliquot. Similar values were obtained on the heparinized specimen only for 2 weeks, after which there was a significant decrease in measurable EP concentration.

Table 1 gives the means, SD, and SE for determinations in 490 children $1-5$ years of age to their nearest birthday. They are considered a normal population as far as lead poisoning is concerned, since their blood lead concentrations were less than 30 $\mu \mathrm{g} / \mathrm{dl}$ whole blood. In only four instances was it possible to know whether a child had iron deficiency anemia or not. The result from these four iron-deficient children are not included. There was no difference among children with "normal" blood lead concentration whether the test was a first screening or a repeat examination. Table 2 gives these results as well as the values in other children with higher concentrations of blood lead. Fifty-two percent of children with blood lead concentrations of $40-59 \mu \mathrm{g} / \mathrm{dl}$ had EP determinations of less than $60 \mu \mathrm{g} / \mathrm{dl}$. Among children with a second blood lead concentration of $40-59 \mu \mathrm{g} / \mathrm{dl}, 24 \%$ had EP concentrations of less than $60 \mu \mathrm{g} / \mathrm{dl}$. There were four children 4-5 years of age who had 6-12 tests over a period of a year or more which revealed mean blood lead concentrations of $44 \mu \mathrm{g} / \mathrm{dl}$ with a range of $39-55 \mu \mathrm{g} / \mathrm{dl}$. At the end of this time, at least

Table 1. Erythrocyte protoporphyrin values in children with blood lead concentrations of less than $30 \mu \mathrm{g} / \mathrm{dl}$

\begin{tabular}{|c|c|c|c|c|}
\hline Age, years & No. & $\begin{array}{c}\text { Mean erythrocyte } \\
\text { protoporphyrin } \\
(\mu \mathrm{g} / \mathrm{dl} \text { whole } \\
\text { blood })\end{array}$ & ${ }_{ \pm} \mathrm{SD}$ & ${ }_{ \pm} \mathrm{SE}$ \\
\hline $1-5$ & 490 & 34.7 & 13.41 & 0.61 \\
\hline $1+2$ & 208 & 38.6 & 12.35 & 0.86 \\
\hline $3+4+5$ & 282 & 31.9 & 13.47 & 0.80 \\
\hline
\end{tabular}

Table 2. Erythrocyte protoporphyrin values related to blood lead concentrations

\begin{tabular}{ccccccc}
\hline & \multicolumn{3}{c}{$\begin{array}{c}\text { Mean } \\
\text { protopor- } \\
\text { phyrin }\end{array}$} & & \multicolumn{3}{c}{$\begin{array}{c}\text { \% Children with } \\
\text { protoporphyrin }\end{array}$} \\
\cline { 5 - 7 } $\begin{array}{c}\text { Lead } \\
\text { conc., } \mu \mathrm{g} / \mathrm{dl}\end{array}$ & No. & $\begin{array}{c}\text { ( } \mu \mathrm{g} / \mathrm{dl}) \\
\end{array}$ & \pm SEM & $>60$ & $>190$ \\
\hline$<30$ & 490 & 34.7 & 0.61 & 8 & 0.2 \\
$30-39$ & 562 & 47.5 & 1.09 & 22 & 1.0 \\
$40-49$ & 267 & 67.9 & 3.16 & 45 & 4.5 \\
$50-59$ & 109 & 112.2 & 8.79 & 54 & 16.5 \\
$60+$ & 95 & 158.1 & 15.48 & 72 & 26.3 \\
\hline
\end{tabular}

two EP determinations were less than $60 \mu \mathrm{g} / \mathrm{dl}$. Of the 27 children with blood lead concentrations of $60 \mu \mathrm{g} / \mathrm{dl}$ or more (all values but one of 74 were below $70 \mu \mathrm{g} / \mathrm{dl}$ ) and simultaneous EP concentrations of less than 60,7 have not as yet been reexamined. Ten had second tests confirming the elevated lead concentration and had elevated EP concentrations on this test. Ten on re-examination had normal concentrations of both $\mathrm{Pb}$ and EP. None of the results herein reported differs significantly from results obtained in this laboratory from similar children by the method of Piomelli in September-December 1975 (2).

\section{SUMMARY}

Values for erythrocyte protoporphyrin in the blood of children as determined by the direct reading fluorometer have been presented as a reference for those planning to use such instruments as they become available. It should be noted that all of these deterninations were made in the summer when it might be expected that the values would be relatively high in relation to the blood lead concentrations. The increase in so-called normal values (from children with lead concentrations of less than $30 \mu \mathrm{g} / \mathrm{dl}$ whole blood) in the younger children, aged 1-2 years, presumably reflects the high incidence of iron deficiency in this group over that in children 3-5 years of age. Some of the increase in concentration of EP in children who had blood lead concentrations of $30-39 \mu \mathrm{g} / \mathrm{dl}$ stems from the inclusion of children with previously higher blood lead concentrations. One major drawback in the use of EP determinations in lead poisoning with this method remains. Even after specimens with falsely elevated lead concentrations from contamination or laboratory error as well as specimens from children with transient elevations of blood lead are eliminated from consideration, a significant number of children with blood lead concentrations of $40-60 \mu \mathrm{g} / \mathrm{dl}$ have erythrocyte protoporphyrin concentrations in the normal range. This is a physiologic, not a methodologic limitation.

\section{REFERENCES AND NOTES}

1. Lamola, A. A., Joselow, M., and Yamane, T.: Zinc Protoporphyrin (ZPP): A simple, sensitive fluorometric screening test for lead poisoning. Clin. Chem., 21: 93 (1975).

2. Piomelli, S.: A micromethod for free erythrocyte porphyrins: The FEP test. J. Lab. Clin. Med., 81: 932 (1973).

3. Kindly made available by Dr. J. Eisinger, Bell Laboratories, Murray Hill, N. J.

4. Requests for reprints should be addressed to: R. Klein, M.D., Childhood Lead Poisoning Prevention Program, The Commonwealth of Massachusetts Department of Health, 305 South St., Jamaica Plain, Mass. 02130 (USA).

5. Accepted for publication February 17, 1976. 